\title{
DAMPAK LIBERALISASI TARIF IMPOR PADA INVESTASI TEKNOLOGI PERUSAHAAN MANUFAKTUR INDONESIA
}

\author{
Diah Ekaningtyas \\ diah.ty@gmail.com \\ Vid Adrison \\ Fakultas Ekonomi dan Bisnis, Universitas Indonesia
}

\begin{abstract}
The purpose of this study is to analyze the reduction of import tariff impact on technological investment in Indonesian manufacturing companies. In this research, we are using samples from large medium manufacturing industry from IBS database during 2003-2014 with Tobit Regression Method as econometrical hypothesis testing. In theory, tariff liberalization can increase or decrease technological investment. Differences in the level of efficiency (gap technology) between companies causing diverge firm's response to the tariff liberalization. When the firm's technological gap in the country with small frontier then the competition level encourages technological investment. However, when the technological gap is large then theoretically there are two possibilities of firm's response. Large technological gap can lowering or increasing technological investment. Indonesia is a developing country where the average efficiency level is small. Therefore, it is expected that manufacturing technological gap in Indonesia compared to its large frontier. Based on the regression result, we have known that greater the tariff reduction lead higher technological investment. In addition, we found an evidence that firm with small technological gaps have greater technoloical investments than firms with large technological gaps. Technological investment of firms with large technological gaps are done for survive.
\end{abstract}

Key words: tariffliberalization; technological investment; manufacture; Indonesia

\section{ABSTRAK}

Penelitian ini bertujuan menganalisis dampak penurunan tarif impor pada investasi teknologi perusahaan manufaktur di Indonesia. Sampel penelitian ini adalah seluruh sektor industri manufaktur menengah besar (IBS) tahun 2003-2014. Pengujian hipotesis menggunakan pendekataan ekonometri dengan metode regresi tobit. Secara teori, liberalisasi tarif dapat meningkatkan atau menurunkan investasi teknologi. Perbedaan tingkat efisiensi (gap teknologi) perusahaan yang menyebabkan respon perusahaan terhadap liberalisasi tarif berbeda-beda. Ketika gap teknologi perusahaan di dalam negeri dengan frontier kecil maka peningkatan kompetisi mendorong investasi teknologi. Akan tetapi, ketika gap teknologinya besar maka secara teori terdapat dua kemungkinan yaitu menurunkan atau meningkatkan investasi teknologi. Indonesia merupakan negara berkembang di mana rata-rata tingkat efisiensinya kecil, sehingga di duga gap teknologi perusahaan manufaktur di Indonesia dibandingkan frontier-nya besar. Berdasarkan hasil regresi diketahui semakin besar penurunan tarif semakin tinggi investasi teknologi yang dilakukan. Selain itu, terbukti bahwa perusahaan dengan gap teknologi yang kecil memiliki investasi teknologi yang lebih besar dibandingkan perusahaan dengan gap teknologi yang besar. Perusahaan dengan gap teknologi yang besar melakukan investasi teknologi hanya untuk bertahan.

Kata kunci: liberalisasi tarif; investasi teknologi; manufaktur; Indonesia

\section{PENDAHULUAN}

Isu terkait perbedaan dampak liberalisasi tarif masih menarik untuk di bahas. Beberapa penelitian membuktikan bahwa liberalisasi tarif memiliki dampak positif bagi produktifitas perusahaan (Fernandes, 2007; Nickel, 1996; Pavcnik, 2002; Tybout dan Westbrook, 1994). Akan tetapi, bebe- 
rapa ekonom membuktikan bahwa liberalisasi memiliki dampak yang beragam pada produktifitas perusahaan (Aghion, Redding, Burgess, dan Zilibotti, 2005; Amiti dan Konings, 2007; Bustos, 2011; Fernandes, 2007; Schor, 2004). Schor (2004), menunjukkan bahwa perbedaan dampak tersebut dikarenakan adanya perbedaan karakteristik perusahaan. Dampak liberalisasi tarif terhadap produktivitas dapat dilihat salah satunya melalui mekanisme peningkatan efisiensi dengan investasi teknologi (Fernandes, 2007).

Efisiensi perusahaan akan mendorong pertumbuhan ekonomi suatu negara (Ridhwan et al., 2015). Salah satu upaya meningkatkan efisiensi perusahaan adalah melakukan investasi teknologi yaitu dengan membeli mesin baru atau memperbaiki mesin. Menurut Orlikowski (1992) teknologi merupakan hardware, peralatan, mesin yang digunakan manusia untuk melakukan proses produksi, meningkatkan produktivitas dan menurunkan biaya organisasi. Dengan demikian, investasi teknologi merupakan upaya perusahaan menjadi lebih kompetitif. Akan tetapi, penurunan tarif impor akan meningkatkan ancaman masuknya perusahaan asing ke pasar dalam negeri. Hal ini akan meningkatkan kompetisi di pasar domestik. Dampak peningkatan kompetisi terhadap investasi teknologi masih menjadi perdebatan hingga saat ini.

Terdapat tiga pandangan ekonom terkait dampak penurunan tarif impor pada investasi teknologi. Menurut Rodrik (1988), peningkatan kompetisi akibat penurunan tarif impor akan mengurangi market share perusahaan dalam negeri sehingga profitnya berkurang. Akibatnya, insentif perusahaan dalam negeri untuk melakukan investasi teknologi akan berkurang (Rodrik, 1988). Rodrik (1988) tidak menemukan alasan yang bagus bagaimana penurunan tarif dapat meningkatkan investasi teknologi perusahaan dan memperpendek gap teknologi dengan perusahaan asing. Meskipun demikian, Rodrik (1988) tidak mempertimbangkan keberagaman gap teknologi perusahaan dalam negeri di dalam modelnya. Di sisi lain, beberapa ekonom berpendapat bahwa penurunan tarif dapat meningkatkan atau menurunkan investasi teknologi di saat bersamaan (Aghion, et al., 2004; Aghion, et al., 2005).

Keberagaman gap teknologi antara perusahaan dalam negeri dengan technological frontier yaitu perusahaan asing menyebabkan penurunan tarif dapat meningkatkan atau menurunkan investasi teknologi di saat bersamaan (Aghion, et al., 2004; Aghion, et al., 2005). Penurunan tarif akan mendorong perusahaan dalam negeri yang berada di dekat technological frontier (gap teknologi kecil) untuk mengejar ketertinggalannya dengan investasi teknologi dan bersaing dengan perusahaan asing. Sebaliknya, penurunan tarif akan menurunkan insentif perusahaan untuk melakukan investasi teknologi jika perusahaan dalam negeri berada jauh dari technological frontier (gap teknologi besar). Hal ini dikarenakan tidak ada kesempatan bagi perusahaan dalam negeri untuk memenangkan kompetisi (Aghion, et al., 2004; Aghion, et al., 2005). Akan tetapi, hal tersebut tidak terbukti pada rata-rata penelitian empiris yang membuktikan pengaruh peningkatan kompetisi adalah positif (Iacovone, 2012).

Ekonom lain berpendapat, penurunan tarif akan mendorong perusahaan dalam negeri dengan gap teknologi yang besar maupun kecil untuk melakukan investasi teknologi (Iacovone, 2012). Menurut Iacovone (2012), perusahaan yang gap teknologi besar (jauh dari technological frontier) tetap akan melakukan investasi teknologi ketika terjadi liberalisasi tarif impor. Intuisinya perusahaan tersebut melakukan investasi teknologi untuk bisa bertahan dan tidak keluar dari pasar. Hal tersebut dikarenakan, untuk bisa catch up dan mengejar ketertinggalannya, perusahaan dengan gap teknologi besar memerlukan upaya investasi teknologi yang lebih besar dibandingkan dengan perusahaan dengan gap teknologi kecil, dan probabilitasnya untuk catch up masih lebih kecil dari perusahaan yang gap 
teknologinya kecil. Sedangkan perusahaan dengan gap teknologi kecil melakukan investasi untuk bisa bersaing dengan perusahaan asing.

Selain penelitian teoritis diatas terdapat beberapa penelitian teoritis lain terkait dampak tarif terhadap waktu adposi teknologi. Beberapa diantaranya adalah Ederington dan Mccalman (2011), Goh (2000) dan Miyagiwa dan Ohno (1995) yang membahas bagaimana tarif mempercepat proses adopsi teknologi atau memperlambatnya. Akan tetapi, penelitian tersebut tidak mempertimbangkan dampak asimetrik yang muncul akibat heterogenitas perusahaan. Selain itu, pengukuran waktu mengadopsi teknologi menyebabkan penelitian tersebut sulit dibuktikan secara empiris.

Beberapa penelitian empiris membukti kan liberalisasi tarif impor meningkatkan insentif perusahaan untuk melakukan investasi teknologi. Liberalisasi tarif menyebabkan perusahaan asing masuk sehingga tingkat kompetisi meningkat. Peningkatan kompetisi mendorong perusahaan untuk meningkatkan efisiensinya melalui investasi teknologi (Iacovone, 2012; Liebman dan Reynolds, 2015; Parameswaran, 2010). Dengan mengontrol tingkat konsentrasi pasar, Parameswaran (2010) menemukan bahwa di India peningkatan kompetisi akibat liberalisasi tarif akan meningkatkan investasi teknologi hanya pada sektor dengan tingkat konsentrasi yang tinggi. Sebaliknya untuk sektor dengan tingkat konsentrasi rendah peningkatan kompetisi justru akan menurunkan investasi teknologi. Penelitian lain seperti Kandilov dan Leblebiciog lu (2012) dan Liebman dan Reynolds (2015) menemukan liberalisasi tarif input lebih penting di banding tarif output, sebagaimana Amiti dan Konings (2007), Schor (2004), Topalova dan Khandelwal (2011). Menurut Kandilov dan Leblebiciog lu (2012) yang meneliti dampak liberalisasi tarif input dan output di Meksiko, semakin besar marginal profitability perusahaan dari capital akibat penurunan tarif input, semakin besar insentif perusahaan untuk berinvestasi, sebaliknya penurunan tarif output justru menambah kompetisi, mengurangi profit, dan insentif untuk melakukan investasi. Meskipun demikian, penelitian-penelitian empiris tersebut tidak mengontrol gap gap teknologi.

Berdasarkan penelitian-penelitian empiris tersebut, hanya penelitian Iacovone (2012) yang mengontrol gap teknologi dan hasilnya signifikan berpengaruh. Dengan menggunakan sampel data Meksiko tahun 1993-2002, ia menemukan semakin kecil jarak dari frontier ketika liberalisasi tarif semakin besar investasi teknologi yang dilakukan perusahaan dan sebaliknya. Dengan demikian, gap teknologi merupakan faktor penting yang perlu dikontrol dalam penelitian dampak liberalisasi tarif terhadap investasi teknologi perusahaan, jika tidak dikontrol dikhawatirkan menjadi omitted variable bias.

Perkembangan teknologi perusahaan manufaktur di Indonesia cukup baik, namun tidak sebanding dengan perkembangan share sektor manufaktur (Okamoto dan Sjöholm, 2001). Pertumbuhan ekspor sektor manufaktur Indonesia cukup tinggi dari 4\% pada tahun 1980 menjadi $56 \%$ pada tahun 1997. Akan tetapi, kenaikan ekspor tersebut terjadi pada sektor yang bukan berbasis teknologi tinggi namun padat karya dan menggunakan banyak sumberdaya alam seperti industri makanan, pakaian, alas kaki, dan mainan. Bahkan hingga tahun 2014, sebagian besar ekspor manufaktur Indonesia merupakan ekspor dengan tingkat teknologi rendah (Ridhwan et al., 2015). Demikian juga dengan industri berbasis teknologi seperti elektronik dan otomotif.

Share ekspor industri elektronik berada di atas $12 \%$ pada tahun 1996, namun nilai tambahnya dibawah 4\% (Okamoto dan Sjöholm, 2001). Hal ini menunjukkan bahwa industri elektronik berfokus pada kegiatan perakitan bahan baku impor dan tidak mengembangkannya sendiri dengan menggunakan sumber daya yang ada. Upaya pengembangan teknologi pada sektor manufaktur di Indonesia masih sangat rendah (Okamoto dan Sjöholm, 2001). Pengeluaran rata-rata sektor manufaktur 
Indonesia untuk melakukan upaya pengembangan teknologi masih sangat kecil. Bahkan industri dengan insentif RdanD yang tinggi seperti farmasi pengeluaran RdanD-nya hanya $0,24 \%$ per output. Demikian pula dengan industri tekstil, garmen dan elektronik. Perusahaan domestik yang dimiliki asing memiliki nilai tambah yang lebih baik dibandingkan perusahaan lokal. Meskipun demikian, sebagian besar nilai tambah tersebut diperoleh melalui spillover teknologi bahan baku impor, sehingga perusahaan asing yang ada di dalam negeri juga tidak melakukan pengembangan teknologi yang baik. Kondisi tersebut diatas di duga menyebabkan gap teknologi perusahaan di dalam negeri dengan perusahaan di luar menjadi besar.

Di sisi lain, liberalisasi tarif yang terjadi sejak pertengahan tahun 1980-an menyebabkan kompetisi di sektor manufaktur terus meningkat hingga tahun 2014. Data WITS menunjukkan perubahan rata-rata tarif MFN Indonesia dari tahun 2003 hingga 2014 telah berada di bawah $10 \%$. Rata-rata tarif MFN Indonesia (ISIC 4 digit) pada tahun 2003-2014 semakin menurun. Hanya beberapa sektor yang masih memiliki tarif yang cukup tinggi yaitu pertama, industri pengolahan tembakau, kedua, makanan dan minuman, dan ketiga, industri kendaraan bermotor. Hal ini menunjukkan bahwa kompetisi yang terjadi pada tahun 2003 hingga 2014 sudah cukup tinggi.

Data BPS menunjukkan sejak tahun 2003 terjadi kenaikan impor barang modal selain alat angkutan yang di duga merupakan bentuk investasi dalam menghadapi peningkatan kompetisi. Di satu sisi tarif impor semakin rendah di sisi lain investasi meningkat. Meskipun demikian, jika dilihat dari penggunaan energi, sektor industri memiliki tren yang meningkat. Hal tersebut menunjukkan efisiensi industri di Indonesia masih rendah, sehingga di duga rata-rata gap teknologi dengan perusahaan asing cukup besar sebagaimana penelitian Okamoto dan Sjöholm (2001) dan Ridhwan et al. (2015).
Dengan demikian, dampak penurunan tarif impor pada investasi teknologi perusahaan manufaktur di Indonesia bisa meningkatkan investasi sebagaimana penelitian Iacovone (2012) atau menurunkannya sebagaimana penelitian Aghion et al. (2004, 2005). Hal inilah yang menjadi gap pada penelitian ini. Tujuan penelitian ini adalah untuk menganalisis dampak liberalisasi tarif impor pada investasi teknologi perusahaan manufaktur di Indonesia.

\section{TINJAUAN TEORETIS}

Teori pasar menjelaskan bahwa salah satu karakteristik pasar oligopoli adalah keputusan satu perusahaan akan mempengaruhi harga pasar dan keuntungan pesaingnya. Liberalisasi tarif akan menyebabkan meningkatnya ancaman entry. Vives (2008) menjelaskan bahwa penurunan tarif akan menurunkan biaya entry sehingga meningkatkan peluang perusahaan masuk (kompetitor meningkat), namun perusahaan akan masuk ketika melihat masih terdapat profit pada pasar tersebut. Lebih lanjut, Iacovone (2012) menjelaskan bahwa perusahaan asing akan melihat perkembangan teknologi yang ada di dalam negeri sebelum masuk ke pasar domestik.

Ketika tarif impor tinggi dan gap teknologi dengan perusahaan dalam negeri kecil maka perusahaan asing tidak akan masuk. Ketika tarif impor tinggi dan gap teknologi besar, maka terdapat kemungkinan perusahaan asing masuk. Demikian pula ketika tarif impor rendah dan gap teknologinya kecil. Akan tetapi ketika tarif rendah dan gap teknologinya besar maka besar kemungkinan perusahaan asing akan masuk. Ketika perusahaan asing memutuskan untuk masuk ke pasar domestik maka supply di pasar domestik meningkat, sehingga harga menjadi turun. Kondisi tersebut yang kemudian di respon oleh perusahaan di dalam negeri.

Aghion (2002) maupun Aghion et al. (2004, 2005) menjelaskan ada dua respon perusahaan terhadap peningkatan kompetisi 
yang terjadi yaitu bersaing dengan new entrance dengan meningkatkan investasi teknologi atau tidak dapat bersaing karena expected profit-nya menurun sehingga investasinya mengecil (Schumpeterian effect). Lebih lanjut, Aghion et al. (2005) menjelaskan perusahaan akan melakukan investasi teknologi ketika penurunan profit sebelum melakukan investasi teknologi lebih besar dibanding kan penurunan profit setelah melakukan investasi teknologi. Hal tersebut terjadi pada perusahaan yang produktivitasnya dekat dengan frontier (gap teknologinya kecil) agar tidak kehilangan seluruh pasar. Untuk perusahaan yang produktivitasnya jauh dari frontier, peningkatan kompetisi akibat penurunan tarif akan menyebabkan penurunan profit sebelum melakukan investasi teknologi lebih kecil dibandingkan penurunan profit setelah melakukan investasi teknologi, sehingga ia memutuskan untuk tidak bersaing dan tidak melakukan investasi teknologi.

Adanya jarak (kesenjangan) antara produktivitas perusahaan dengan produktivitas frontier disebabkan adanya gap teknologi antara keduanya. Sebagai mana disampaikan Aghion et al. (2005) dan Fernandes (2007) bahwa investasi teknologi merupakan penggerak pertumbuhan perusahaan. Dengan demikian, mengikuti teori Iacovone (2012) perbedaan gap teknologi antara perusahaan di dalam negeri dan perusahaan asing menyebabkan perbedaan respon perusahaan akibat liberalisasi tarif impor. Ketika gap teknologi antara perusahaan di dalam ngeri dan perusahaan asing kecil maka peningkatan kompetisi akibat liberalisasi tarif akan mendorong perusahaan di dalam negeri untuk meningkatkan investasi teknologinya untuk dapat bersaing, sedangkan ketika gap teknologinya kecil, maka peningkatan kompetisi akibat liberalisasi tarif mendorong perusahaan di dalam negeri untuk meningkatkan investasi teknologinya untuk bertahan. Secara detail konseptual penelitian ini adalah sebagai berikut:

\section{Produksi Perusahaan di dalam Negeri}

Mengikuti Aghion et al. (2004) dan Iacovone (2012), perusahaan dalam negeri dan perusahaan asing memproduksi barang yang sama sebagaimana karakter pada teori pasar oligopoli. Di dalam negeri, barang $y$ diproduksi dengan menggunakan satu kontinum intermediate input $v$, di mana $v \in[0,1]$ dengan fungsi produksi sebagai berikut:

$y_{t}=\frac{1}{\alpha}\left[\int_{0}^{1} A_{t}^{1-\alpha}(v) x_{t}^{\alpha}(v) d v\right]$.

$x_{t}(v)$ merupakan jumlah intermediate input $v$ pada tahun $t, A_{t}(v)$ mengukur produktivitas pada tahun $t$, dan $\alpha \in(0,1)$. Barang $y$ merupakan final good yang bisa langsung dikonsumsi atau digunakan kembali sebagai intermediate input. Dengan demikian, $y$ merupakan fungsi dari produktivitas dan intermediate input $(v)$ yang diproduksi oleh monopolist atau diproduksi sendiri.

Iacovone (2012) menjelaskan profit yang akan diperoleh oleh perusahaan dalam negeri dengan memproduksi barang $y$ akan berbanding terbalik dengan seberapa kuat kompetisi yang terjadi (konsentrasi pasar $\delta(\chi))$ dan sebanding dengan produktivitas perusahaan di dalam negeri.

$\pi(v)=A_{t}(v) \delta(\chi)$

di mana $\delta(\chi)=(\chi-1) \frac{\chi^{\frac{1}{\alpha-1}}}{\alpha}$ dan $\chi$ merupakan parameter yang menggambarkan intensitas persaingan yang bernilai lebih besar dari 1.

Dari persamaan (2), perusahaan dalam negeri harus memperbesar produktivitasnya untuk dapat memaksimumkan profit-nya. Produktivitas mencerminkan tingkat teknologi yang digunakan oleh perusahaan. Semakin tinggi teknologi yang digunakan maka semakin besar produktivitas perusahaan sehingga semakin besar keuntungan yang akan diperoleh. Meskipun demikian, semakin kuat kompetisi yang terjadi di pasar maka semakin kecil profit yang akan diperoleh. Untuk itu, perusahaan dalam negeri perlu melakukan investasi teknologi untuk dapat mempertahankan atau meningkatkan profit yang diperoleh. 


\section{Keputusan Investasi Teknologi}

Sebagaimana dalam model yang dibangun Iacovone (2012), pada penelitian ini, teknologi perusahaan asing yang tercermin dari tingkat produktivitasnya $\left(A_{t}^{f}\right)$ diasumsikan sebagai technological frontier sehingga $A_{t}^{f}=\bar{A}_{t}$.

Mengikuti Iacovone (2012), di setiap periode technological frontier $\left(\bar{A}_{t}\right)$ berkembang secara eksogen pada tingkat $g$.

$\bar{A}_{t}=\bar{A}_{t-1}(1+g)$.

Pada setiap akhir periode, teknologi perusahaan akan ter-upgrade secara otomatis dengan asumsi bahwa terjadi spillover teknologi dari perusahaan yang lebih maju sehingga perusahaan berada satu tingkat lebih maju (Iacovone, 2012). Meskipun demikian, masih terdapat lag teknologi antara perusahaan asing dan perusahaan di dalam negeri. Di dalam negeri terdapat dua tipe perusahaan yaitu advanced firm di mana pada akhir $t-1$ produktivitasnya $\left(A_{t-1}^{d}\right)$ sama dengan teknologi frontier sebelumnya $\left(A_{t-1}^{d}=A_{t-1}^{f}\right)$ dan backward firm di mana pada akhir $t-1$ produktivitasnya sama dengan teknologi frontier dua periode sebelumnya $\left(A_{t-1}^{d}=A_{t-2}^{f}\right)$.

Diasumsikan advanced firm melakukan investasi teknologi dan berhasil catch up dengan probabilitas $z$. Sedangkan ketika backward firm melakukan investasi teknologi dan berhasil maka posisinya masih berada satu tingkat di bawah frontier, belum dapat catch up dengan teknologi frontier sehingga butuh upaya ekstra untuk menyamakan tingkat teknologi (two steps ahead). Probabilitas upaya ekstra backward firm untuk sukses diasumsikan dengan $s$, di mana $s$ selalu lebih kecil dari $z$ yaitu $s=\theta z$. Karena pada setiap akhir periode diasumsikan terjadi spillover teknologi termasuk pada backward firm maka nilai $\theta$ tidak akan kurang dari $g$, sehingga $g \leq \theta<1$.

Hal inilah yang membedakan penelitian Iacovone (2012) dengan penelitian Aghion et al. (2004, 2005), di mana backward firm mungkin untuk catch up dengan teknologi frontier.
Mengikuti Aghion et al. (2005) dan Iacovone (2012), biaya perusahaan di dalam negeri melakukan investasi teknologi merupakan kuadrat dari research effort dan linear pada tingkat teknologi yang digunakan untuk berproduksi pada saat itu.

$c_{1 t}=\frac{1}{2} z^{2} A_{t-1}^{f}(v)$.

Dikarenakan backward firm melakukan two steps ahead sebagaimana dijelaskan di atas, maka biaya investasi backward firm merupakan kuadrat dari research effort dan linear pada tingkat teknologi dua periode sebelumnya $\left(A_{t-1}^{d}=A_{t-2}^{f}\right)$ ditambah dengan biaya investasi upaya ekstra dengan probabilitas sukses $s$, sebagai berikut:

$c_{2 t}=\frac{1}{2} z^{2} A_{t-2}^{f}(v)+\frac{1}{2} s^{2} A_{t-2}^{f}(v)$

di mana $c_{1 t}$ adalah biaya investasi teknologi advanced firm, $c_{2 t}$ adalah biaya investasi teknologi backward firm, $A_{t-1}^{f}(v)$ adalah produktivitas advanced firm dengan tingkat teknologi selisih satu tingkat dengan teknologi frontier, dan $A_{t-2}^{f}(v)$ adalah produktivitas backward firm dengan tingkat teknologi selisih dua tingkat dengan teknologi frontier. Dengan demikian, pada setiap periode $t$ akan ada perusahaan yang keluar dari pasar dan digantikan oleh new advanced firm pada $t+1$.

\section{Dampak Penurunan Tarif Impor}

Penurunan tarif impor akan menyebabkan ancaman entry meningkat (Aghion et al., 2004, 2005; Iacovone, 2012). Iacovone (2012) menjelaskan, sebelum masuk ke pasar domestik perusahaan asing akan mengamati bagaimana kondisi teknologi yang digunakan oleh perusahaan di dalam negeri. Jika terdapat gap teknologi antara perusahaan di dalam negeri dan perusahaan asing di mana teknologi perusahaan asing lebih tinggi, maka perusahaan asing akan memutuskan masuk ke pasar domestik. Mengikuti Iacovone (2012), probabilitas perusahaan asing masuk ke pasar domestik adalah sebagai berikut: (a) Probabilitas perusahaan asing masuk $=0$, ketika pada $t-1$ produktivitas perusahaan domestik pada frontier $\left(A_{t}^{d}\right)$, 
sehingga pada $t$ dengan investasi teknologi produktivitasnya menjadi lebih unggul dari perusahaan asing $\left(A_{t+1}^{d}\right)$ atau backward firm di $t-1$ namun berhasil mencapai frontier di $t$; (b) Probabilitas perusahaan asing masuk $=$ $\mu$, ketika pada $t$ teknologi perusahaan asing lebih tinggi dibandingkan perusahaan di dalam negeri $\left(A_{t}^{f}>A_{t}^{d}\right)$.

Dalam penelitian ini telah diasumsikan bahwa terdapat lag teknologi antara perusahaan asing dan perusahaan di dalam negeri sehingga probabilitas perusahaan asing masuk adalah $\mu$.

\section{Dampak Liberalisasi Tarif terhadap Investasi Teknologi}

Teori Cournot menjelaskan bahwa setiap perusahaan akan menghasilkan output yang memaksimalkan keuntungannya. Salah satu mekanismenya yaitu melakukan investasi teknologi. Terkait dengan hal tersebut model Iacovone (2012) menjelaskan perusahaan di dalam negeri melakukan investasi teknologi untuk meningkatkan keuntungan. Sebagaimana telah dijelaskan di atas, ketika advanced firm $\left(A_{t-1}^{d}=A_{t-1}^{f}\right)$ berhasil melakukan investasi teknologi maka produktivitasnya menjadi sama dengan frontier $\left(A_{t-1}^{d}=A_{t}^{f}\right)$, namun ketika tidak berhasil maka produktivitasnya tetap tertinggal dari frontier $\left(A_{t-1}^{d}=A_{t-1}^{f}\right)$. Demikian juga dengan backward firm $\left(A_{t-1}^{d}=A_{t-2}^{f}\right)$. Mengikuti Iacovone (2012), terdapat empat kemungkinan backward firm ketika melakukan investasi teknologi yaitu pertama, berhasil maju selangkah menuju frontier $\left(A_{t-1}^{d}=A_{t-1}^{f}\right)$, kedua, tidak berhasil maju selangkah sehingga produktivitasnya tidak berubah $\left(A_{t-1}^{d}=A_{t-2}^{f}\right)$, ketiga berhasil melakukan upaya ekstra sehingga produktivitasnya sama dengan frontier $\left(A_{t-1}^{d}=A_{t}^{f}\right)$ atau keempat tidak berhasil melakukan upaya ekstra sehingga produktivitasnya tidak berubah $\left(A_{t-1}^{d}=A_{t-2}^{f}\right)$. Expected profit maximization problem dari hackward firm di dalam negeri ketika melakukan investasi teknologi dengan konstrain biaya investasi adalah sebagai berikut:

$\max _{z} E\left[\pi_{2 t}\right]=\delta(\chi)\left[z(1-\mu) A_{t-1}^{f}+(1-z)(1-\right.$ н) $\left.A_{t-2}^{f}+s A_{t}^{f}+(1-s) A_{t-2}^{f}(1-\mu)\right]-\frac{1}{2}\left(z^{2}+\right.$ $\left.s^{2}\right) A_{t-2}^{f}$

di mana $A_{t}^{f}$ adalah produktivitas frontier pada saat $\mathrm{t}, \quad z$ adalah probabilitas backward firm sukses untuk satu langkah lebih maju dengan produktivitas $A_{t-1}^{f}$ sehingga dapat mempertahankan pasar ketika tidak ada perusahaan asing yang masuk $(1-\mu)$. Sedangkan, $1-z$ adalah probabilitas backward firm tidak sukses untuk maju satu langkah dan produktivitas tetap $A_{t-2}^{f}$ dan tetap dapat mempertahankan pasarnya jika tidak ada perusahaan asing yang masuk. Upaya ekstra untuk bisa catch up dengan frontier probabilitasnya $s$ dengan produktivitas $A_{t}^{f}$ untuk mempertahankan pasarnya. Akan tetapi, ketika tidak sukses $(1-s)$ maka produktivitasnya tetap $A_{t-2}^{f}$ dan dapat mempertahankan pasar ketika tidak ada perusahaan asing yang masuk.

Berdasarkan persamaan (6) solusi expected profit maximization problem adalah investasi teknologi yang optimal $\left(z_{2 t}^{*}\right)$ oleh backward firm:

$z_{2 t}^{*}=\frac{\delta}{1+\theta^{2}}[g(1+2 \theta+\theta g)+\mu(\theta-g)] \ldots . .(7)$

Ketika terjadi penurunan tarif, maka perusahaan asing akan masuk sebesar $\mu$, sehingga investasi yang memaksimumkan keuntungan perusahaan backward firm ketika terjadi penurunan tarif adalah:

$\frac{d z_{2 t}^{*}}{d \mu}=\frac{\delta}{1+\theta^{2}}(\theta-g)$

Sedangkan pada advanced firm, expected profit maximization problem dengan konstrain biaya investasi adalah:

$\max _{z} E\left[\pi_{1 t}\right]=\delta(\chi)\left[z A_{t}^{f}+(1-z)(1-\right.$

н) $\left.A_{t-1}^{f}\right]-\frac{1}{2} z^{2} A_{t-1}^{f}$

di mana probabilitas advanced firm akan sukses catch up dan produktivitas $A_{t}^{f}$ adalah $z$ yaitu ketika perusahaan asing keluar dari pasar domestik. Advanced firm tetap akan 
mempertahankan pasar jika investasi teknologi dilakukan tidak berhasil dengan probabilitas $1-z$ dan tingkat produktivitas $A_{t-1}^{f}$, serta perusahaan asing tidak masuk.

Berdasarkan persamaan (9) expected profit maximization problem adalah investasi teknologi yang optimal $\left(z_{1 t}^{*}\right)$ advanced firm:

$z_{1 t}^{*}=\delta(g+\mu)$.

Ketika terjadi penurunan tarif impor maka perusahaan asing akan masuk sebesar $\mu$ sehingga investasi advanced firm yang akan memaksimumkan keuntungannya ketika terjadi penurunan tarif adalah:

$\frac{d z_{1 t}^{*}}{d \mu}=\delta$.

Berdasarkan persamaan (8) dan (11) maka diketahui bahwa penurunan tarif akan meningkatkan investasi teknologi bagi advanced firm lebih besar dibandingkan backward firm. Dengan demikian, penurunan tarif impor akan meningkatkan investasi teknologi baik advanced firm maupun backward firm. Hal ini lah yang akan dibuktikan secara empiris. Akan tetapi, konseptual ini tidak mempertimbangkan kompetisi yang terjadi di luar negeri.

\section{Hasil Penelitian Terdahulu}

Tidak banyak penelitian terkait dampak penurunan tarif terhadap investasi teknologi, namun dampaknya dapat dilihat melalui pendekatan produktivitas. Beberapa penelitian empiris membuktikan bahwa penurunan tarif meningkatkan produktivitas perusahaan (Amiti dan Konings, 2007; Pavcnik, 2002; Topalova dan Khandelwal, 2011). Hal tersebut menunjukkan bahwa peningkatan kompetisi akibat penurunan tarif mendorong perusahaan menjadi lebih produktif. Tingkat produktivitas perusahaan menunjukkan tingkat efisiensinya. Semakin tinggi produktivitas perusahaan maka semakin tinggi tingkat efisiensinya, sebaliknya semakin rendah produktivitasnya maka semakin rendah efisiensinya. Sementara itu, tingkat efisiensi akan menggambarkan teknologi yang digunakan. Dengan demikian, semakin besar gap teknologi antar perusahaan maka semakin jauh perbedaan tingkat efisiensi antar perusahaan dan semakin besar perbedaan produktivitasnya.

Secara empiris penelitian terkait dampak penurunan tarif terhadap investasi teknologi pernah dilakukan di negara berkembang ataupun negara maju. Di Meksiko, Kandilov dan Leblebiciog `lu (2012) menemukan bahwa penurunan tarif input akan meningkatkan investasi teknologi pada tahun 1984-1990. Hal tersebut dikarenakan penurunan tarif input akan menurunkan biaya impor input sehingga marginal profitability dari capital akan meningkat. Perusahaan akan berinvestasi ketika marginal cost investasi teknologi sama dengan discounted value marginal return terhadap capital saat ini. Semakin besar marginal profitability dari capital, semakin besar insentif perusahaan untuk berinvestasi. Semakin banyak perusahaan mengimpor input produksinya maka semakin kuat peningkatan investasinya. Sebaliknya, penurunan marginal profitability dari capital akan menurunkan insentif perusahaan untuk berinvestasi. Sementara itu, penurunan tarif output tidak berdampak signifikan terhadap investasi teknologi dikarenakan penurunan tarif akan meningkatkan kompetisi dan mengurangi profit perusahaan.

Liebman dan Reynolds (2015) meneliti dampak penurunan tarif terhadap investasi teknologi di Amerika tahun 1974-2005. Sedikit berbeda dengan Kandilov dan Leblebiciog lu (2012), mereka menemukan penurunan tarif output berdampak positif dan signifikan terhadap investasi teknologi, konsisten dengan teori bahwa penurunan tarif akan meningkatkan investasi teknologi perusahaan. Demikian juga penurunan tarif input yang memiliki dampak positif terhadap investasi. Hal tersebut menunjukkan penurunan tarif input meningkatkan akses perusahaan untuk memperoleh input lebih berkualitas dengan harga lebih murah, dan meningkatkan peluang keuntungan serta insentif investasi. Akan tetapi, ketika tarif input dan tarif output dimasukkan bersama ke dalam model, maka tarif output tidak lagi berdampak signifikan. Menurut Liebman 
dan Reynolds (2015), hasil tersebut menunjukkan dampak penurunan tarif output bukan dikarenakan peningkatan kompetisi perusahaan, tetapi dikarenakan peningkatan akses sumberdaya input yang lebih berkualitas.

Penelitian lainnya adalah penelitian Parameswaran (2010). Ia menemukan bahwa dampak tarif terhadap investasi teknologi dipengaruhi oleh kompetisi impor, ekspor dan impor teknologi. Ekspor dan impor teknologi berpengaruh positif terhadap investasi teknologi, namun tidak dengan kompetisi impor. Peningkatan kompetisi akibat penurunan tarif impor akan meningkatkan investasi teknologi hanya pada sektor dengan tingkat konsentrasi pasar yang tinggi. Sebaliknya, pada sektor dengan tingkat konsentrasi pasar yang rendah, peningkatan kompetisi justru akan menurunkan investasi teknologi.

Iacovone (2012) meneliti keberagaman respon perusahaan di Meksiko akibat penurunan tarif terhadap produktivitas. Menurutnya keberagaman respon tersebut dikarenakan jarak dari frontier. Dalam penelitiannya, ia menunjukkan bahwa tarif akan mempengaruhi produktivitas melalui beberapa chanel diantaranya pengurangan inefisiensi, peningkatan penggunaan kapital, peningkatan investasi teknologi dan peningkatan inovasi.

Terkait dampak penurunan tarif impor terhadap investasi teknologi, ia menemukan bahwa penurunan tarif meningkatkan investasi teknologi. Selain itu, semakin kecil gap teknologinya (dekat dari frontier) semakin besar investasi teknologi yang dilakukan.

\section{Hipotesis Penelitian}

Menurut Iacovone (2012), peningkatan kompetisi akibat liberalisasi tarif akan mendorong perusahaan untuk meningkat kan investasi teknologi baik perusahaan dengan gap teknologi kecil maupun besar. Dengan demikian, di duga liberalisasi tarif akan meningkatkan insentif perusahaan untuk melakukan investasi teknologi. Maka:
Ho : tarif berdampak negatif pada investasi teknologi.

\section{METODE PENELITIAN \\ Sumber Data}

Penelitian ini akan menggunakan data perusahaan manufaktur besar sedang, data tarif. Data perusahaan manufaktur besar sedang (IBS) diperoleh dari Badan Pusat Statistik Republik Indonesia dengan mengambil tahun sampel 2003-2014. Adapun data tarif dan impor diperoleh dari sumber internasional WITS. Data nilai tukar diperoleh dari data Wordbank.

\section{Model Empiris}

Berdasarkan kerangka konseptual di atas, maka dampak penurunan tarif impor akan diuji dengan mengukur gap teknologi perusahaan di dalam negeri dengan frontier. Jika gap teknologi merupakan kesenjangan tingkat teknologi antara perusahaan dalam negeri dengan frontier yang tercermin dari perbedaan produktivitasnya, maka sebagaimana persamaan (3) gap teknologi merupakan jarak produktivitas perusahaan dalam negeri dan frontier sebagai berikut:

$\bar{A}_{t}=\bar{A}_{t-1}(1+g)$

$g=\frac{\bar{A}_{t}}{\bar{A}_{t-1}}-1$

Dengan asumsi bahwa produktivitas perusahaan dalam negeri $\left(\bar{A}_{t-1}\right)$ tertinggal 1 periode dibandingkan frontier $\left(\bar{A}_{t}\right)$.

Mengikuti penelitian Iacovone (2012), produktivitas perusahaan di ukur dari value added per tenaga kerja per tahun $\left(\pi_{i j t}\right)$. Produktivitas fontier didekati dari rata-rata value added per tenaga kerja per tahun $\left(\pi_{j t}^{F}\right)$ dari lima perusahaan di dalam negeri dengan nilai terbesar dengan asumsi bahwa rata-rata nilai tersebut setara dengan produktivitas perusahaan asing (frontier). Karena di setiap akhir periode perusahaan akan upgrade teknologi secara otomatis karena adanya spillover teknologi dari industri sudah maju maka pada periode $t$ produktivitas frontier domestik menjadi sama dengan produktivitas perusahaan asing saat masuk. Sebagaimana persamaan 
(13) maka gap teknologi perusahaan di dalam negeri terhadap frontier adalah produktivitas frontier di bagi produktivitas perusahaan di dalam negeri $\left(\right.$ Dist $\left._{i j t}=\frac{\pi_{j t}^{F}}{\pi_{i j t}}\right)$.

Keputusan investasi perusahaan pada periode $t$ didasarkan pada kondisi yang terjadi di periode sebelumnya $(t-1)$. Ketika terjadi perubahan kondisi seperti penurunan tarif di periode $t$, maka perubahan tersebut tidak dapat langsung diakomodir. Untuk itu, dalam penelitian ini variabel independen utama maupun kontrol diuji pada periode $t-1$ dan mengontrol shock makro yang terjadi di setiap tahun, sebagaimana penelitian Iacovone (2012), sehingga model empirisnya adalah:

$$
\begin{aligned}
\text { Inv }_{i t}=\alpha \text { Tarif }_{j t-1} & \\
& +\beta_{1} \text { Dist }_{i j t-1}+\beta_{2} \text { Dist }_{i j t-1} \\
& * \text { Tarif }_{j t-1}+X_{i t-1} \gamma_{0}+\varepsilon_{i t}
\end{aligned}
$$

di mana :

$$
\begin{array}{ll}
\operatorname{Inv}_{i} & : \text { investasi teknologi perusahaan } i \\
\text { Tarif }_{j} & : \text { tarif sektor } j ; \\
\text { Dist }_{i j} & : \text { gap teknologi perusahaan } i \text { pada } \\
& \text { sektor } j \text { terhadap frontier; } \\
X_{i} & : \text { vektor variabel yang mempe- } \\
& \text { ngaruhi keputusan investasi ber- } \\
& \text { dasarkan pada penelitian-pe- } \\
& \text { nelitian terkait. }
\end{array}
$$

Menurut Thoenig dan Verdier (2003), investasi teknologi identik dengan penggunaan skill labour. Senada dengan Aghion (2002), inovasi teknologi akan mengakibatkan wage inequality antara skill labor dan unskill labour. Dengan demikian, biaya tenaga kerja akan mencerminkan penggunaan skill labor dalam proses produksi yang dapat menggambarkan adanya investasi. Untuk itu, biaya tenaga kerja perlu dikontrol. Demikian juga biaya kapital, karena teknologi kapital akan menggambarkan biaya kapital yang digunakan (Hendricks, 2000).

Selain itu, ekspor memiliki pengaruh yang signifikan terhadap investasi teknologi. Ketika tarif impor negara tujuan diturunkan mendorong perusahaan di dalam negeri untuk berkompetisi untuk memasuki pasar asing dan meningkatkan profit. Hal tersebut meningkatkan insentif perusahaan di dalam negeri untuk melakukan investasi teknologi. Bustos (2011) dan Parameswaran (2010) menemukan ekspor memiliki korelasi positif tehadap investasi teknologi. Dengan demikian, share ekspor perlu di kontrol dalam penelitian ini. Namun karena keterbatasan data share ekspor, maka penelitian ini menggunakan dummy ekspor sebagai kontrol.

Tarif input memiliki dampak yang lebih penting dengan tarif output terhadap investasi teknologi. Secara empiris, Kandilov dan Leblebiciog lu (2012) dan Liebman dan Reynolds (2015) menemukan dampak keduanya berbeda. Tarif input berdampak negatif terhadap investasi teknologi sedangkan tarif output berdampak positif (Kandi-

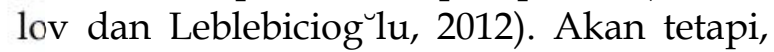
menurut Liebman dan Reynolds (2015) tarif input lebih berpengaruh dibandingkan tarif output. Hal tersebut terbukti ketika tarif output dan tarif input dimasukkan bersamasama dalam model hasilnya tarif outlput menjadi tidak signifikan. Menurutnya, dampak tarif terhadap investasi bukan dikarenakan faktor kompetisi melainkan faktor impor input. Dikarenakan data tarif impor tidak tersedia, maka penelitian ini hanya akan mengkontrol faktor impor input yang diproksikan oleh share impor input terhadap total input, untuk menghilangkan kemungkinan terjadinya multikoleniaritas dengan nilai tambah maka digunakan dummy impor.

Athukorala dan Kohpaiboon (2010) menjelaskan perilaku investasi teknologi yang berbeda pada perusahaan dengan kepemilikan asing. Perusahaan dengan kepemilikan asing, pada umumnya melakukan aktivitas inovasi di perusahaan induknya. Inovasi di perusahaan di dalam negeri akan dilakukan untuk meningkatkan pasar dan daya saing, sehingga keputusan investasi teknologi akan dipengaruhi oleh keputusan perusahaan induknya. Dengan demikian investasi yang dilakukan oleh perusahaan berkepemilikan asing pada umumnya me- 
miliki nilai yang besar, karena dilakukan bukan hanya untuk perusahaan di dalam negeri tetapi juga untuk cabangnya yang lain. Untuk itu, status kepemilikan perusahaan perlu dikontrol.

Parameswaran (2010) menjelaskan ukuran perusahaan, konsentrasi impor, dan penetrasi impor merupakan faktor-faktor yang secara signifikan mempengaruhi keputusan perusahaan untuk melakukan investasi teknologi ketika terjadi liberalisasi tarif. Menurutnya, liberalisasi tarif akan meningkatkan investasi teknologi pada pasar yang terkonsentrasi, namun berlaku sebaliknya pada pasar yang tidak terkonsentrasi. Sedangkan menurut (Kandilov dan Leblebicioğlu, 2011), nilai tukar juga akan mempengaruhi keputusan investasi teknologi secara signifikan. Ketika perusahaan menggunakan bahan baku impor atau mengekspor output yang dihasilkan, maka perubahan nilai tukar akan berpengaruh terhadap biaya produksi atau ekspektasi profit yang dihasilkan di mana keduanya mempengaruhi keputusan perusahaan melakukan investasi teknologi.

Dengan mempertimbangkan hal-hal tersebut diatas, model empiris yang akan digunakan dalam penelitian ini adalah:

$$
\begin{aligned}
\text { Inv }_{i t}=\alpha \text { Tarif }_{j t-1} & \\
& +\beta_{1} \text { Dist }_{i j t-1}+\beta_{2} \text { Dist }_{i j t-1} \\
& * \text { Tarif }_{j t-1}+X_{i t-1} \gamma_{0}+\varepsilon_{i t}
\end{aligned}
$$

di mana :

Inv $v_{i} \quad$ : investasi teknologi perusahaan $i$;

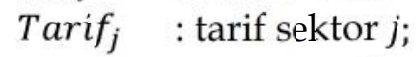

Dist $_{i j} \quad$ : gap teknologi perusahaan $i$ pada sektor $j$ terhadap frontier;

$X_{i t} \quad$ : vektor variabel yang terdiri dari nilai tambah, biaya tenaga kerja dan biaya kapital, dummy impor, dummy ekspor, penetrasi impor, ukuran perusahaan dan konsentrasi impor, nilai tukar dan status perusahaan $i$ pada tahun ke $\mathrm{t}-1$.

Dampak tarif terhadap investasi teknologi akan diketahui dari koefisien $\alpha$, dengan hipotesis $\alpha$ bernilai negatif, sedangkan untuk dampak gap teknologi terhadap investasi teknologi $\left(\beta_{1}\right)$ diekspektasikan akan bernilai positif. Perbedaan jarak teknologi mendorong perusahaan untuk melakukan upaya lebih untuk bersaing yaitu dengan meningkatkan investasi teknologi. Interaksi antara jarak dan tarif $\left(\beta_{2}\right)$ akan menggambarkan bagaimana dampak perbedaan jarak ketika terjadi liberalisasi tarif. Berdasarkan teori yang di bangun mengikuti penelitian Iacovone (2012) maka $\beta_{2}$ diekspektasikan bernilai positif.

\section{Definisi Operasional Variabel}

Penelitian ini akan menganalisis dampak tarif terhadap investasi teknologi pada perusahaan manufaktur di Indonesia. Definisi operasional masing-masing variabel yang digunakan adalah sebagai berikut: Variabel utama investasi teknologi (y) dan tarif (x). Investasi teknologi adalah rasio dari nilai pembelian atau penambahan mesin dan perlengkapan pada level perusahaan per nilai kapital stok periode sebelumnya. Variabel kedua adalah tarif. Tarif (\%) adalah rata-rata MFN tarif per ISIC 4 digit per tahun. Variabel jarak teknologi adalah rasio dari produktivitas frontier terhadap produktivitas perusahaan, yaitu rata-rata value added per tenaga kerja frontier terhadap value added per tenaga kerja perusahaan di dalam negeri.

Selain variabel utama, penelitian ini menggunakan beberapa variabel sebagai kontrol yaitu nilai tambah, biaya tenaga kerja, biaya kapital, dummy impor, dummy ekspor, dan status perusahaan. Variabel nilai tambah merupakan rasio dari nilai tambah perusahaan per nilai output. Variabel biaya tenaga kerja merupakan rasio dari nilai upah tenaga kerja perusahaan per nilai output. Variabel biaya kapital merupakan rasio dari biaya listrik di bagi dengan total kwh penggunaan listrik per nilai output. Variabel selanjutnya adalah dummy impor. Dummy impor adalah dummy status impor input perusahaan, bernilai 1 jika impor dan 0 jika tidak. Selanjutnya, dummy ekspor adalah 
dummy status ekspor perusahaan. Dummy ekspor akan bernilai 0 jika perusahaan tidak mengekspor hasil produksinya dan bernilai 1 jika sebaliknya. Variabel status perusahaan (owner) merupakan dummy status yang bernilai 1 ketika $>50 \%$ modal perusahaan merupakan modal asing, dan 0 jika $\leq 50 \%$ modal perusahaan merupakan modal dalam negeri.

Variabel penetrasi impor merupakan rasio dari impor dibagi dengan total ouput sektor (impor dan domestik), sedangkan ukuran perusahaan diproksikan dengan jumlah pekerja baik produksi maupun non produksi. Konsentrasi impor diproksikan dengan penetrasi impor dikali dengan konsentrasi pasar (HHI). Konsentrasi pasar (HHI) merupakan jumlah dari market share kuadrat untuk seluruh perusahaan, di mana market share merupakan rasio dari nilai produksi dibagi ouput sektor. Sedangkan nilai tukar diproksikan dengan real effective exchange rate.

\section{Teknik Analisis Data}

Besaran investasi teknologi perusahaan tidak dibatasi besarannya. Investasi teknologi perusahaan satu dan perusahaan lain bervariasi di setiap tahunnya. Tidak semua perusahaan melakukan investasi di tahun yang sama. Ada perusahaan yang berinvestasi dalam jumlah besar, ada yang berinvestasi dalam jumlah kecil, dan ada yang tidak berinvestasi. Hal tersebut menyebabkan data menjadi truncated (corner solution). Dengan tipe data variabel independen demikian, maka penelitian ini melakukan regresi menggunakan tobit sebagai metode estimasinya. Analisis dilakukan di level perusahaan, dan untuk robustness check penelitian ini dilakukan dengan membandingkan proksi investasi teknologi yaitu investasi teknologi per nilai kapital stok sebelumnya dengan investasi teknologi per nilai ouput.

\section{ANALISIS DAN PEMBAHASAN Analisis Deskriptif}

Dikarenakan liberalsiasi tariff di Indo- nesia sudah dimulai sejak tahun 1980-an, maka di tahun 2003-2004 rata-rata tarif MFN Indonesia sudah cukup rendah dan perubahannya kecil. Hanya beberapa sektor yang masih memiliki tarif yang cukup tinggi yaitu pertama, industri pengolahan tembakau, kedua, makanan dan minuman, dan ketiga, industri kendaraan bermotor.

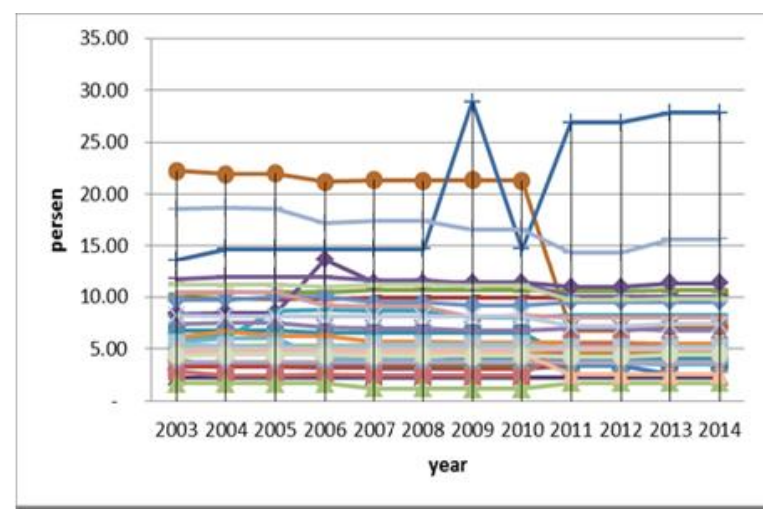

\section{Gambar 1 \\ Rata-rata Tarif MFN Indonesia Tahun 2003-2014}

Sumber : WITS, telah diolah kembali

Industri yang memiliki rata-rata tarif MFN diatas $15 \%$ antara lain industri pengolahan tembakau, makanan dan minuman, dan kendaraan bermotor.

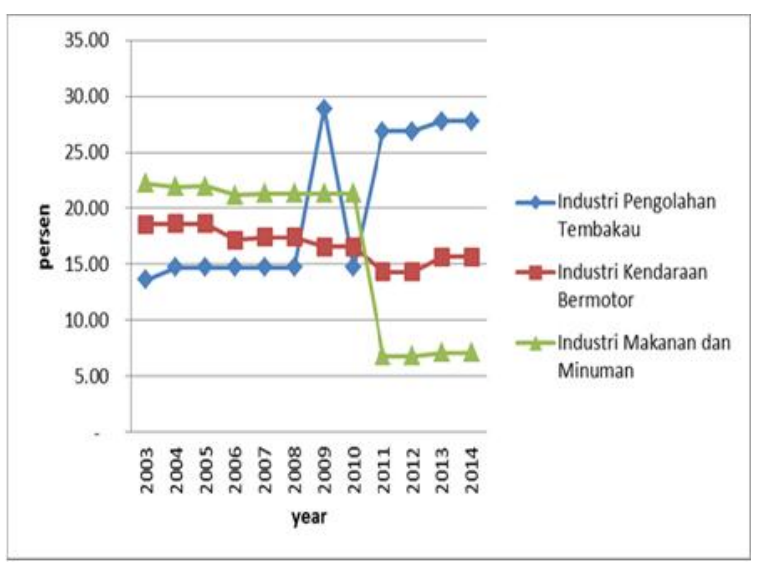

Gambar 2

Pergerakan Tarif MFN 3 industri dengan tarif tertinggi

Sumber : WITS, telah diolah kembali

Jika dibandingkan dengan data investasinya per tahunnya industri kendaraan bermotor merupakan industri terbesar ke-3 
dari 25 sektor industri yang memiliki investasi terbesar, sedangkan industri makanan dan minuman berada di posisi ke4 terbesar dan industri pengolahan tembakau pada posisi ke-17 dari 25 sektor industri. Untuk industri dengan tarif yang sangat rendah (di bawah 11\%) dan pergerakannya sangat kecil justru memiliki nilai investasi yang kecil dan stabil, kecuali industri mesin listrik lainnya dan perlengkapannya serta industri kertas, barang dari kertas dan sejenisnya. Kedua industri tersebut memiliki rata-rata nilai investasi terbesar di antara industri lainnya pada periode tahun 20032014. Nilai investasi teknologi yang tinggi pada industri kertas, barang dari kertas dan sejenisnya di duga karena adanya peraturan tetang lingkungan hidup yang ketat sehingga untuk memenuhi syarat-syarat di dalam peraturan tersebut perusahaan harus meningkatkan teknologinya dengan investasi, sedangkan nilai investasi teknologi yang tinggi pada industri mesin listrik lainnya dan perlengkapannya di duga terjadi karena harga mesin yang mahal sehingga mempengaruhi nilai investasinya.

Berdasarkan status ekspor, perusahaan pengekspor memiliki nilai investasi technologi yang lebih besar dibandingkan perusahaan yang tidak mengekspor.

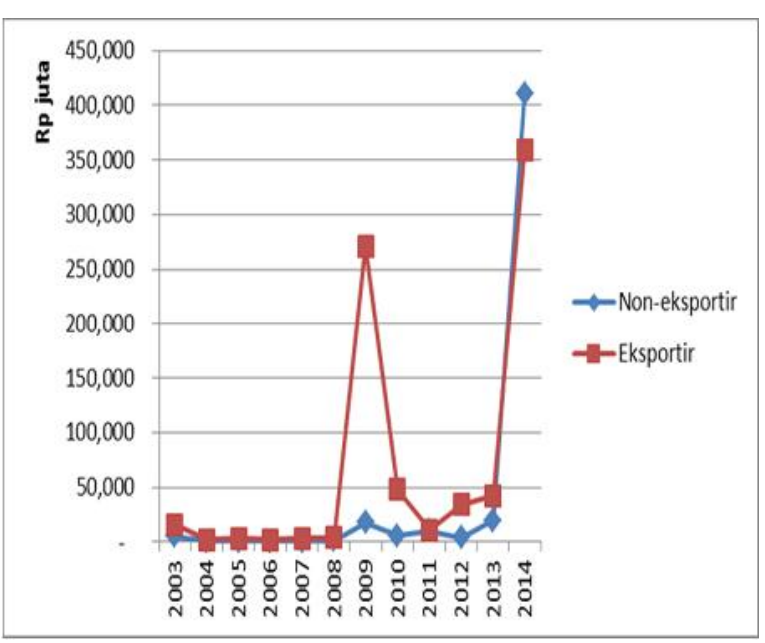

Gambar 3

Investasi teknologi perusahaan eksportir-non eksportir

Sumber : Badan Pusat Statistik, telah diolah kembali
Hal tersebut sesuai dengan hasil penelitian Bustos (2011) di mana dampak lain liberalisasi tarif mendorong perusahaan di dalam negeri untuk masuk ke pasar asing untuk memperoleh revenue lebih banyak. Kenaikan revenue mendorong perusahaan di dalam negeri untuk meningkatkan efisiensinya untuk bersaing di pasar asing melalui investasi teknologi. Untuk itu, perusahaan yang melakukan ekspor memiliki kecenderungan nilai investasi lebih tinggi dibandingkan dengan perusahaan yang tidak melakukan ekspor, sedangkan berdasarkan data kepemilikan perusahaan (PMA, PM$\mathrm{DN})$, perusahaan PMA pada umumnya memiliki jaringan perusahaan lain di luar negeri dan kantor pusat yang mengatur pengembangan perusahaan termasuk investasi. Karena itu, pada umumnya investasi teknologi dilakukan bukan hanya untuk pengembangan satu perusahaan tetapi beberapa perusahaan yang dimiliki, sehingga nilai investasinya besar. Sebagaimana dijelaskan oleh Athukorala dan Kohpaiboon (2010), meskipun reseach and development dilakukan di perusahaan pusat, namun perusahaan PMA lokal tetap memerlukan investasi teknologi untuk penyesuaian produk dengan kondisi dan peraturan lokal guna peningkatan produksi dan mempertahankan daya saing.

Analisis deskriptif untuk variabel utama yaitu investasi teknologi, tarif dan jarak seperti pada tabel 1. Berdasarkan tabel 1 diketahui bahwa investasi teknologi per output mengalami fluktuasi di setiap tahun. Investasi terbesar terjadi pada tahun 2009. Di duga hal tersebut di duga karena perusahaan mulai bangkit akibat krisis 2008 . Meskipun demikian, setelah tahun 2009 terdapat kecenderungan nilai investasi teknologi semakin lama semakin membesar.

Demikian juga dengan data tarif pada tabel 2 yang mengalami fluktuasi di setiap tahun, tetapi setelah tahun 2009 rata-rata tarif tidak mengalami perubahan yang signifikan. Rata-rata penurunan tarif terbesar pada sampel data terjadi di tahun 2011. Meskipun demikian, hubungan investasi 
teknologi dan tarif impor tidak dapat dijelaskan secara linear karena ada faktor lain yang mempengaruhi. Adapun analisis des- kriptif jarak ketika terjadi penurunan tarif dapat dijelaskan pada tabel 3.

Tabel 1

Analisis Deskriptif Variabel Investasi Teknologi

\begin{tabular}{ccrcccc}
\hline \hline Variable & Year & \multicolumn{1}{c}{ Obs } & Mean & Std.Dev. & Min & Max \\
\hline & 2003 & 7,333 & $8.44 \mathrm{E}+06$ & $2.84 \mathrm{E}+08$ & 0 & $1.93 \mathrm{E}+10$ \\
& 2004 & 6,999 & $1.20 \mathrm{E}+06$ & $2.15 \mathrm{E}+07$ & 0 & $1.06 \mathrm{E}+09$ \\
& 2005 & 8,353 & $1.41 \mathrm{E}+06$ & $3.05 \mathrm{E}+07$ & 0 & $2.45 \mathrm{E}+09$ \\
& 2006 & 12,863 & $9.33 \mathrm{E}+05$ & $1.14 \mathrm{E}+07$ & 0 & $5.42 \mathrm{E}+08$ \\
Tech. & 2007 & 12,565 & $1.72 \mathrm{E}+06$ & $2.22 \mathrm{E}+07$ & 0 & $9.21 \mathrm{E}+08$ \\
Investment & 2008 & 11,615 & $1.98 \mathrm{E}+06$ & $3.24 \mathrm{E}+07$ & 0 & $2.80 \mathrm{E}+09$ \\
& 2009 & 11,195 & $6.86 \mathrm{E}+07$ & $5.16 \mathrm{E}+09$ & 0 & $5.32 \mathrm{E}+11$ \\
& 2010 & 11,168 & $1.57 \mathrm{E}+07$ & $1.10 \mathrm{E}+09$ & 0 & $1.15 \mathrm{E}+11$ \\
& 2011 & 9,777 & $8.07 \mathrm{E}+06$ & $3.50 \mathrm{E}+08$ & 0 & $3.32 \mathrm{E}+10$ \\
& 2012 & 14,542 & $1.12 \mathrm{E}+07$ & $5.10 \mathrm{E}+08$ & 0 & $4.93 \mathrm{E}+10$ \\
& 2013 & 3,911 & $2.10 \mathrm{E}+07$ & $8.46 \mathrm{E}+08$ & 0 & $7.81 \mathrm{E}+10$ \\
& 2014 & 1,747 & $2.24 \mathrm{E}+08$ & $9.51 \mathrm{E}+09$ & 0 & $7.89 \mathrm{E}+11$ \\
\hline
\end{tabular}

Tabel 2

Analisis Deskriptif Variabel Tarif Impor

\begin{tabular}{ccccccc}
\hline \hline Variable & Year & Obs & Mean & Std. Dev & Min & Max \\
\hline \multirow{5}{*}{ Import Tariff } & 2003 & 6,104 & 8.87 & 4.94 & 0.00 & 33.69 \\
& 2004 & 5,843 & 9.14 & 5.00 & 0.00 & 33.97 \\
& 2005 & 7,534 & 9.19 & 7.98 & 0.00 & 154.76 \\
& 2006 & 11,695 & 9.82 & 6.92 & 0.00 & 138.57 \\
& 2007 & 11,403 & 9.49 & 6.24 & 0.00 & 123.33 \\
& 2008 & 10,542 & 9.34 & 6.39 & 0.00 & 123.33 \\
& 2009 & 10,202 & 9.41 & 7.08 & 0.00 & 139.71 \\
& 2010 & 10,097 & 9.13 & 6.08 & 0.00 & 123.33 \\
& 2011 & 8,865 & 8.55 & 4.60 & 1,12 & 30.00 \\
& 2013 & 13,263 & 8.55 & 4.61 & 1,12 & 26.86 \\
& 2014 & 12,700 & 8.72 & 5.14 & 0.00 & 27.80 \\
& 10,617 & 8.49 & 4.49 & 0.00 & 27.80 \\
\hline
\end{tabular}

Berdasarkan tabel 3 diketahui bahwa gap teknologi perusahaan manufaktur di Indonesia ketika terjadi penurunan tarif sangat bervariasi. Gap teknologi terbesar tejadi di tahun 2007 dengan nilai rata-rata gap teknologi per usahaan di dalam negeri lebih dari 1. Jika dibandingkan dengan tabel 1 diatas maka terdapat kecenderungan setelah tahun 2009 semakin lama gap teknologi perusahaan manufaktur ketika terjadi penurunan tarif semakin membesar dan semakin lama nilai investasi teknologi juga semakin membesar. Hal tersebut menunjukkan bahwa di duga perubahan gap teknologi perusahaan manufaktur mendorong perusahaan meningkatkan efisiensinya ketika terjadi penurunan tarif dengan meningkatkan investasi teknologinya. Meskipun demikian hubungannya terhadap investasi teknologi masih dipengaruhi faktor-faktor lain. 
Jika di lihat dari sisi persaingannya, maka tingkat kompetisi di pasar domestik masih merupakan persaingan sempurna. Hal ini terbukti analisis deskriptif pada table 4

Tabel 3

Analisis Deskriptif Interaksi Variabel Jarak dan Tarif

\begin{tabular}{ccccccr}
\hline \hline Variable & Year & Obs & Mean & Std. Dev & Min & \multicolumn{1}{c}{ Max } \\
\hline & 2003 & 6,104 & 0.65 & 30.86 & 0.00 & $2,410.93$ \\
& 2004 & 5,843 & 0.37 & 0.79 & 0.00 & 6.66 \\
& 2005 & 7,534 & 0.22 & 1.12 & 0.00 & 71.68 \\
& 2006 & 11,695 & 1.54 & 8.46 & 0.00 & 385.73 \\
Distance * & 2007 & 11,403 & 1.70 & 63.72 & 0.00 & $5,531.71$ \\
Tariff & 2008 & 10,542 & 0.97 & 2.40 & 0.00 & 23.03 \\
& 2009 & 10,202 & 0.80 & 2.00 & 0.00 & 43.28 \\
& 2010 & 10,097 & 0.58 & 1.18 & 0.00 & 16.88 \\
& 2011 & 8,865 & 0.58 & 2.44 & 0.00 & 149.81 \\
& 2012 & 13,263 & 0.55 & 3.94 & 0.00 & 305.46 \\
& 2013 & 12,700 & 0.69 & 2.37 & 0.00 & 120.73 \\
& 2014 & 10,617 & 0.66 & 21.14 & 0.00 & $2,176.82$ \\
\hline
\end{tabular}

Tabel 4

Analisis Deskriptif Tingkat Persaingan

\begin{tabular}{lccccc}
\hline \hline \multicolumn{1}{c}{ Variable } & Obs & Mean & Std. Dev & Min & Max \\
\hline Import Penetration & 118,875 & 0.26 & 0.24 & 0.00 & 1.00 \\
Market Concentration & 132,984 & 0.10 & 0.14 & 0.00 & 1.00 \\
Import Concentration & 118,875 & 0.03 & 0.07 & 0.00 & 1.00 \\
\hline
\end{tabular}

Berdasarkan tabel 4 diketahui bahwa rata-rata tingkat konsentrasi pasar adalah $10 \%$. Hal ini menunjukkan bahwa pasar sektor manufaktur di Indonesia masih merupakan pasar persaingan sempurna, dan belum terjadi tindakan monopoli. Tingkat penetrasi impor yang terjadi pada tahun 2003-2014 sebesar 26\% dengan konsentrasi sebesar 3\%. Tingkat konsentasi impor yang rendah menunjukkan bahwa perusahaan manufaktur di dalam negeri cukup kompetitif dibandingkan dengan perusahaan asing. Hal tersebut di duga dikarenakan liberalisasi tarif yang terjadi sejak tahun 1980-an. Pada awal-nya peningkatan kompetisi akibat liberalisasi tarif akan menyaring perusahaan dengan tingkat efisiensi yang tinggi. Perusahaan dengan tingkat efisiensi yang rendah akan keluar dari pasar, dan perusahaan yang efisien akan bertahan.
Meskipun demikian, perlu dilakukan pengujian dengan regresi untuk mengetahui dampak liberalisasi tarif pada investasi teknologi.

\section{Dampak Liberalisasi Tarif pada Investasi teknologi}

Hasil regresi (tabel 5) menunjukkan bahwa penurunan tarif impor berpengaruh positif terhadap investasi teknologi perusahaan (tarif berdampak negarif pada investasi teknologi). Hal ini sejalan dengan teori Iacovone (2012) bahwa pada level perusahaan, liberalisasi tarif secara rata-rata akan meningkatkan investasi teknologi perusahaan baik dengan gap teknologi kecil maupun besar. Selain itu, diketahui bahwa jarak tidak menunjukkan korelasi dengan investasi teknologi (tidak signifikan). Ini menunjukkan bahwa jarak bukanlah satu- 
satunya faktor yang akan mempengaruhi keputusan perusahaan untuk berinvestasi dalam teknologi. Penurunan tarif merupakan faktor lain yang mendorong perusahaan berinvestasi di bidang teknologi. Hasil interaksi jarak dan tarif sangat penting untuk investasi teknologi. Hasil regresi menunjukkan bahwa interaksi keduanya berdampak positif terhadap investasi teknologi, di mana perusahaan dengan gap teknologi yang kecil memiliki nilai investasi teknologi yang lebih besar dibandingkan dengan perusahaan dengan gap teknologi yang besar. Kondisi ini membuktikan teori Iacovone (2012) bahwa liberalisasi meningkatkan investasi teknologi lebih besar pada perusahaan dengan gap teknologi yang kecil (advanced firm) dibandingkan perusahaan yang memiliki gap teknologi besar (backward firm), dan bertolak belakang dengan teori Aghion et al. (2004, 2005) yang menyatakan bahwa liberalisasi tarif justru akan menurunkan investasi teknologi backward firm. Untuk kasus Indonesia, hal ini menunjukkan bahwa perbedaan gap antara advanced firm dan backward firm terlalu jauh, sehingga advanced firm yang dekat dari frontier dan hanya membutuhkan sedikit usaha untuk mengejar ketinggalan dan berkompetisi dengan kompetitor asing. Akan tetapi, backward firm yang terlalu jauh dari frontier melakukan investasi teknologi hanya untuk bertahan menghadapi liberalisasi. Data BPS membuktikan kesenjangan teknologi (gap teknologi) antara advanced firm dan backward firm sebagai berikut.

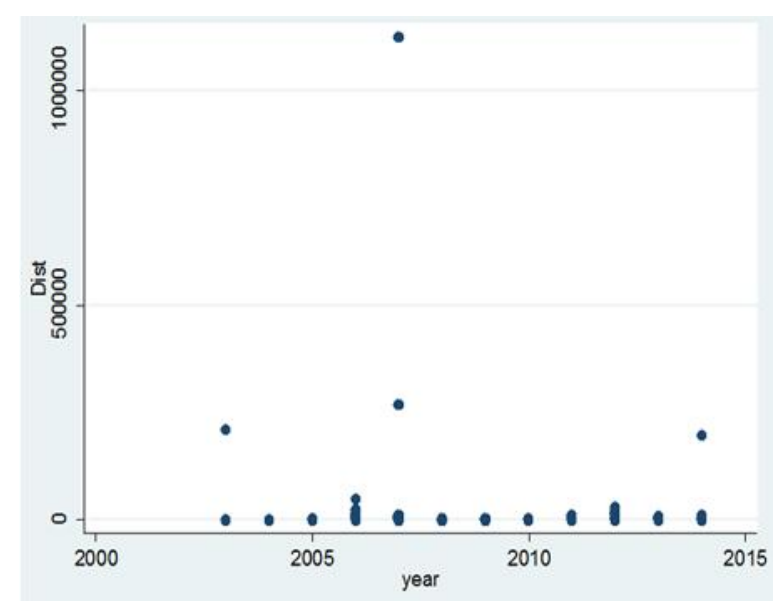

\section{Gambar 4}

Gap teknologi per tahun

Sumber : Badan Pusat Statistik, telah diolah kembali

Periode liberalisasi tarif yang panjang sejak tahun 1980an menjadi seleksi alam bagi perusahaan. Perusahaan yang mampu mengejar kesenjangan teknologi dengan perusahaan asing akan bertahan, sebaliknya perusahaan tidak efisien karena perbedaan kesenjangan teknologi yang terlalu jauh dengan perusahaan asing akan keluar dari pasar. Dengan demikian, rata-rata perusahaan yang tersisa pada periode 2003-2014 adalah perusahaan manufaktur yang mampu meminimalkan kesenjangan teknologi dengan perusahaan asing, walaupun berada pada tingkat backward firm yaitu memiliki kesenjangan teknologi yang besar dengan perusahaan asing. Salah satu faktor yang di duga menyebabkan rata-rata perusahaan manufaktur Indonesia berada pada posisi backward firm adalah teknologi yang digunakan.

\section{Tabel 5}

\section{Dampak Liberalisasi tarif terhadap investasi teknologi}

\begin{tabular}{llr}
\hline \hline model & $\begin{array}{c}\text { Import Tariff } \\
\text { (lagged) }\end{array}$ & $\begin{array}{c}\text { Technological } \\
\text { Investment } \\
\text { (I/Kt-1) }\end{array}$ \\
& $\begin{array}{r}\text { Distance } \\
\text { (lagged) }\end{array}$ & -27.82 \\
& $(7.55)^{* * *}$ \\
Distance * & -0.44 \\
tarif(lagged) & -0.24 \\
& Labor Cost \\
(lagged) & 0.04 \\
Capital Cost & $(2.53)^{* *}$ \\
(lagged) & 0.03 \\
& $(12.71)^{* * *}$ \\
_cons & 0.32 \\
Value Added & -0.61 \\
(lagged) & -2271.54 \\
& $(2.49)^{* *}$ \\
\end{tabular}




\begin{tabular}{|c|c|c|}
\hline & & $\begin{array}{c}\text { Technological } \\
\text { Investment } \\
\text { (I/Kt-1) }\end{array}$ \\
\hline & & -0.52 \\
\hline & \multirow{3}{*}{$\begin{array}{l}\text { Import Dummy } \\
\text { (lagged) }\end{array}$} & 675.68 \\
\hline & & $(14.27)^{\star * *}$ \\
\hline & & 314.21 \\
\hline & \multirow[t]{2}{*}{ Owner (lagged) } & $(5.32)^{* * *}$ \\
\hline & & 514.61 \\
\hline & \multicolumn{2}{|l|}{ Export } \\
\hline & \multirow[t]{2}{*}{ Dummy(lagged) } & $(11.85)^{* * *}$ \\
\hline & & 0.22 \\
\hline & \multicolumn{2}{|l|}{ Firm } \\
\hline & \multirow[t]{2}{*}{ Size(Lagged) } & $(9.70)^{* * *}$ \\
\hline & & -7.49 \\
\hline & \multirow{3}{*}{$\begin{array}{l}\text { Exchange Rate } \\
\text { (lagged) } \\
\text { Import }\end{array}$} & \\
\hline & & -0.82 \\
\hline & & \\
\hline & \multirow{2}{*}{$\begin{array}{l}\text { Penetration } \\
\text { (lagged) }\end{array}$} & -187.88 \\
\hline & & $(2.29)^{* *}$ \\
\hline & \multicolumn{2}{|l|}{ Import } \\
\hline & \multirow{2}{*}{\multicolumn{2}{|c|}{$\begin{array}{l}\text { Concentration } \\
\text { (lagged) }\end{array}$}} \\
\hline & & \\
\hline & \multicolumn{2}{|l|}{ Market } \\
\hline & \multirow{2}{*}{$\begin{array}{l}\text { Concentration } \\
\text { (lagged) }\end{array}$} & -25.63 \\
\hline & & -0.17 \\
\hline & \multirow{3}{*}{$\begin{array}{l}\text { Year FE } \\
\text { _cons }\end{array}$} & Yes \\
\hline sigma & & 2759.41 \\
\hline & & $(149.99)^{* * *}$ \\
\hline $\mathrm{N}$ & & $36,206.00$ \\
\hline
\end{tabular}

Perusahaan membutuhkan opportunities yang sangat besar saat memutuskan untuk menggunakan teknologi terbaru. Hal ini menyebabkan backward firm melakukan investasi teknologi tanpa mengunakan teknologi terbaru. Intuisinya, perusahaan manufaktur di Indonesia melakukan investasi teknologi untuk bertahan di pasar domestik. Hal ini sesuai dengan penelitian Hendricks (2000), bahwa negara berkembang akan berinvestasi dengan teknologi usang karena keterbatasan kemampuan tenaga kerja. Hal ini sesuai dengan kebijakan industrialisasi di Indonesia yang tidak disertai dengan peningkatan kualitas sumber daya manusianya. Menurut Hendricks (2000) penggunaan teknologi terbaru tidak akan lebih menguntungkan daripada teknologi usang. Meski demikian, peningkatan kompetisi karena penurunan tarif impor tetap akan meningkatkan usaha perusahaan agar lebih efisien melalui investasi teknologi. Adopsi teknologi baru akan meningkatkan output perusahaan dan menghemat biaya produksi (Miyagiwa dan Ohno, 1995). Dengan demikian, semakin besar tarif penurunan investasi perusahaan semakin besar (cateris paribus).

\section{Dampak Variabel Kontrol}

Berdasarkan tabel 5, secara umum variabel kontrol secara signifikan berkorelasi positif terhadap investasi teknologi, kecuali penetrasi impor. Besarnya penetrasi impor akan mempengaruhi keuntungan perusahaan. Pengurangan keuntungan akan menekan insentif untuk investasi teknologi. Untuk itu, penetrasi impor berkorelasi negatif dengan investasi teknologi. Berbeda dengan input impor. Karena adanya kesenjangan teknologi antara perusahaan dalam negeri dan asing, pada umumnya input impor dari luar negeri memiliki kualitas yang lebih tinggi, sehingga untuk memprosesnya diperlukan teknologi yang lebih canggih. Untuk itu, impor input berkorelasi positif dengan investasi teknologi. Semakin banyak input produksi yang diimpor semakin besar investasi teknolgi yang dibutuhkan.

Ekspor berkorelasi positif dengan investasi teknologi, sebagaimana penelitian Bustos (2011) dan Parameswaran (2010) yang menunjukkan bahwa penurunan tarif akan mendorong perusahaan domestik untuk bersaing di pasar luar negeri melalui ekspor. Ekspor meningkatkan pendapatan perusahaan. Untuk memperbesar laba, perusahaan dalam negeri perlu meningkatkan efisiensinya. Hal ini mendorong perusahaan untuk meningkatkan insentif mereka untuk berinvestasi di bidang teknologi.

Biaya tenaga kerja berkorelasi positif dengan investasi teknologi. Perubahan tingkat upah yang besar (UMR) setiap tahun menyebabkan biaya produksi lebih besar, sehingga mendorong perusahaan untuk melakukan efisiensi dengan investasi teknologi. Kepemilikan dan ukuran perusahaan 
berkorelasi positif dengan investasi teknologi. Perusahaan PMA umumnya memiliki jaringan dan kantor perusahaan luar negeri lainnya yang mengatur pengembangan perusahaan termasuk investasi. Oleh karena itu, pada umumnya investasi teknologi dibuat tidak hanya untuk pengembangan satu perusahaan tapi beberapa perusahaan dimiliki, jadi nilai investasinya sangat besar. Namun, PMDN juga akan meningkatkan investasinya untuk bersaing di pasar domestik. Untuk itu, kepemilikan berkorelasi positif dengan investasi teknologi.

Semakin besar perusahaan semakin banyak hasil yang dihasilkannya. Untuk menghasilkan banyak output yang efisien dan kompetitif di pasar domestik, perusahaan perlu meningkatkan efisiensi dan mengurangi biaya produksi. Salah satu cara yang bisa dilakukan adalah investasi teknologi. Berbeda dengan variabel yang dijelaskan di atas, variabel biaya modal dan nilai tambah tidak berpengaruh signifikan terhadap investasi teknologi. Karena biaya modal dihitung dari nilai pemakaian listrik per $\mathrm{KwH}$, diduga karena harga listriknya sama, maka menjadi tidak signifikan. Biaya listrik adalah biaya tetap sehingga apapun outputnya diproduksi atau biayanya tetap. Begitu pula untuk nilai tambah, karena nilai tambahnya adalah perhitungan total input dikurangi total output ditambah komponen nilai tambah maka dugaan multikolinearitas terjadi. Untuk konsentrasi impor dan konsentrasi pasar tidak signifikan, diasumsikan karena memiliki nilai rata-rata kecil dan variasi kecil.

\section{Uji Robust}

Untuk menguji apakah hasil yang ditemukan seperti pada tabel 5 telah tepat, maka perlu dilakukan uji robust. Penelitian ini mencoba mengganti proxy investasi teknologi (investasi teknologi per modal saham sebelumnya) dengan investasi teknologi per output. Peningkatan output bisa terjadi karena investasi teknologi. Hal ini didasarkan pada teori Miyagiwa dan Ohno (1995) yang menunjukkan bahwa kenaikan output karena pengurangan tarif mendorong perusahaan untuk mempercepat proses adopsi teknologi. Hasil regresi adalah pada tabel 6 .

Berdasarkan pada tabel 6 tanda dan signifikasi seluruh variabel utama tidak berubah.

Tabel 6

Robustness test

\begin{tabular}{clrrr}
\hline \hline & & $\begin{array}{c}\text { Tech } \\
\text { Investment } \\
\text { (I/Y) }\end{array}$ & $\begin{array}{c}\text { Tech } \\
\text { Investment } \\
\text { (I/Y) }\end{array}$ & $\begin{array}{c}\text { Tech } \\
\text { Investment } \\
(\mathbf{I} / \mathbf{Y})\end{array}$ \\
\hline model & Import Tariff & -0.366 & -0.366 & -0.358 \\
& (lagged) & $(6.40)^{* * *}$ & $(6.36)^{* * *}$ & $(6.24)^{* * *}$ \\
& Distance & 0.003 & 0.003 & 0.003 \\
(lagged) & -1.29 & -1.29 & -1.4 \\
Distance * tarif & 0 & 0 & 0 \\
(lagged) & $(1.84)^{*}$ & $(1.84)^{*}$ & $(1.94)^{*}$ \\
Labor Cost & 0.001 & 0.001 & 0.001 \\
(lagged) & $(16.23)^{* * *}$ & $(16.23)^{* * *}$ & $(16.25)^{* * *}$ \\
Capital Cost & 0.007 & 0.007 & 0.007 \\
(lagged) & -0.78 & -0.78 & -0.71 \\
_cons & -66.094 & -66.075 & -65.291 \\
Value Added & $(4.53)^{* * *}$ & $(4.52)^{* * *}$ & $(4.47)^{* * *}$ \\
(lagged) & 0 & 0 & 0 \\
& -0.25 & -0.25 & -0.24
\end{tabular}




\begin{tabular}{|c|c|c|c|c|}
\hline & $\begin{array}{l}\text { Import Dummy } \\
\text { (lagoed) }\end{array}$ & $\begin{array}{r}13.727 \\
(18.70)^{* * *}\end{array}$ & $\begin{array}{r}13.732 \\
(18.61)^{* * *}\end{array}$ & $\begin{array}{r}13.811 \\
(18.76)^{* * *}\end{array}$ \\
\hline & Owner & 4.919 & 4.918 & 4.901 \\
\hline & (lagged) & $(5.44)^{* * *}$ & $(5.44)^{* * *}$ & $(5.42)^{* * *}$ \\
\hline & Export Dummy & 9.917 & 9.912 & 9.841 \\
\hline & (lagged) & $(14.81)^{* * *}$ & $(14.70)^{\star \star *}$ & $(14.63)^{* * *}$ \\
\hline & Firm Size & 0.004 & 0.004 & 0.004 \\
\hline & (Lagged) & $(11.77)^{\star \star *}$ & $(11.77)^{\star \star *}$ & $(11.79)^{* * *}$ \\
\hline & Exchange Rate & 0.058 & 0.058 & 0.053 \\
\hline & (lagged) & -0.4 & -0.4 & -0.36 \\
\hline & Import Penetration & -0.359 & -0.402 & -2.095 \\
\hline & (lagged) & -0.23 & -0.24 & -1.63 \\
\hline & Import & -13.2 & -12.786 & \\
\hline & $\begin{array}{l}\text { Concentration } \\
\text { (lagged) } \\
\text { Market }\end{array}$ & $(2.26)^{* *}$ & -1.53 & \\
\hline & Concentration & & -0.236 & -3.992 \\
\hline & (lagged) & & -0.07 & $(1.68)^{*}$ \\
\hline & Year FE & Yes & Yes & Yes \\
\hline sigma & _cons & 48.744 & 48.744 & 48.744 \\
\hline & & $(163.20)^{* * *}$ & $(163.20)^{* * *}$ & $(163.20)^{* * *}$ \\
\hline $\mathrm{N}$ & & 51,229 & 51,299 & 51,299 \\
\hline${ }^{*} p, 0.1$ & $05 ; * * * p<0.01$ & & & \\
\hline
\end{tabular}

Hanya penetrasi impor yang menjadi tidak signifikan, dan konsentrasinya menjadi signifikan. Disamping itu, karena data yang ada memiliki jumlah ISIC yang berbedabeda maka penelitian ini tidak dibatasi pada jumlah ISIC tertentu namun sesuai dengan natural datanya. Untuk membuktikan peng gunaan ISIC yang berbeda tidak bermasalah, maka dilakukan robust test dengan menggunakan menyamakan penggunaan 4 digit ISIC dan hasilnya sama pada regresi sebelumnya.

\section{Kasus Industri Tekstil dan Otomotif}

Industri tekstil dan otomotif merupakan sektor industri yang paling dilindungi pada tahun 1970-an. Karena proteksi yang tinggi menyebabkan tingkat efisiensinya rendah. Setelah terjadi liberalisasi tarif pada tahun 1980-an, kedua sektor tersebut mengalami perubahan signifikan. Dengan demikian, di duga liberalisasi tarif memiliki dampak yang penting bagi kedua sektor tersebut. Hasil regresi pada tabel 7 mencerminkan dampak liberalisasi tarif pada kedua sektor tersebut. Berdasarkan tabel 7, tarif tidak berpengaruh signifikan terhadap investasi teknologi, namun jarak dan jarak interaksi dan tarif berpengaruh signifikan terhadap investasi teknologi. Jarak memiliki efek negatif terhadap investasi teknologi. Ini menunjukkan bahwa semakin besar kesenjangan teknologi semakin kecil investasi teknologi yang bisa dilakukan. Sedangkan interaksi memiliki efek positif, yang menunjukkan investasi yang dilakukan oleh perusahaan dengan gap teknologi kecil lebih besar daripada perusahaan dengan gap teknologi besar. Ini sesuai dengan Iacovone (2012). Secara umum, tabel 6 mengilustrasikan bahwa teknologi sektor otomotif lebih tinggi dari pada sektor tekstil yang mengandalkan kepemilikan, ekspor dan bahan baku.

\section{Perbandingan dengan Studi Sebelumnya}

Tidak banyak penelitian terdahulu yang menguji dampak tarif terhadap investasi teknologi. 
Tabel 7

Hasil regresi sektor Tekstil dan Otomotif

\begin{tabular}{|c|c|c|c|}
\hline & & \multicolumn{2}{|c|}{ Investasi Teknologi } \\
\hline & & Tekstil & Automotive \\
\hline \multirow[t]{29}{*}{ model } & Import Tariff (lagged) & 0.385 & 682.156 \\
\hline & & -0.16 & -1.55 \\
\hline & Distance (lagged) & -0.46 & -177.52 \\
\hline & & $(2.18)^{* *}$ & $(4.28)^{* * *}$ \\
\hline & Distance * tarif(lagged) & 0.032 & 17.433 \\
\hline & & $(1.94)^{*}$ & $(4.43)^{* * *}$ \\
\hline & Labor Cost (lagged) & 0.001 & 0.177 \\
\hline & & $(1.73)^{*}$ & -1.24 \\
\hline & Capital Cost (lagged) & -695.629 & $-267,206.88$ \\
\hline & & $(3.14)^{* * *}$ & $(3.49)^{* * *}$ \\
\hline & _cons & 127.981 & $44,284.20$ \\
\hline & & -0.52 & -0.62 \\
\hline & Import Dummy & 52.918 & $4,040.57$ \\
\hline & (lagged) & $(4.55)^{\star * *}$ & -1.19 \\
\hline & Owner (lagged) & 35.77 & $2,270.62$ \\
\hline & & $(2.76)^{* * *}$ & -0.58 \\
\hline & Export Dummy(lagged) & 21.546 & $4,390.42$ \\
\hline & & $(1.91)^{*}$ & -1.12 \\
\hline & Firm Size(Lagged) & 0.018 & 1.52 \\
\hline & & $(3.48)^{* * *}$ & -0.6 \\
\hline & Exchange Rate & -3.395 & -761.811 \\
\hline & (lagged) & -1.41 & -1.05 \\
\hline & Import Penetration & -14.332 & $2,461.96$ \\
\hline & (lagged) & -0.53 & -0.3 \\
\hline & Import & & \\
\hline & $\begin{array}{l}\text { Concentration } \\
\text { (lagged) }\end{array}$ & & \\
\hline & Market Concentration & -8.826 & $-5,748.93$ \\
\hline & (lagged) & -0.27 & -0.39 \\
\hline & Year FE & Yes & Yes \\
\hline \multirow[t]{2}{*}{ sigma } & _cons & 192.275 & $27,266.46$ \\
\hline & & $(42.30)^{* * *}$ & $(21.64)^{* * *}$ \\
\hline $\mathrm{N}$ & & 3,037 & 657 \\
\hline
\end{tabular}

Penelitian tersebut diantaranya penelitian Kandilov dan Leblebiciog`lu (2012) yang menguji perbedaan dampak tarif impor input dan tarif output terhadap investasi capital di Meksiko, Liebman dan Reynolds (2015) di Amerika Serikat, serta Iacovone (2012) yang menguji keberagaman respon perusahaan akibat liberalisasi tarif. Hanya penelitian Iacovone (2012) dan Liebman dan Reynolds (2015) yang dianggap paling mendekati penelitian ini.

Dampak tarif pada investasi teknologi pada penelitian ini memiliki hasil yang sama dibandingkan dengan hasil Iacovone (2012) 
dan Liebman dan Reynolds (2015). Tarif impor output berdampak negatif terhadap investasi teknologi. Hal tersebut dikarenakan penurunan tarif output meningkatkan kompetisi perusahaan di dalam negeri dengan perusahaan asing. Peningkatan kompetisi mendorong perusahaan di dalam negeri melakukan investasi teknologi. Akan tetapi berbanding terbalik dengan penelitian Kandilov dan Leblebiciog lu (2012) yang menyatakan peningkatan kompetisi justru akan mengurangi profit perusahaan di dalam negeri sehingga insentif inovasi berkurang.

Lebih lanjut, hasil korelasi antara jarak terhadap investasi teknologi maupun interaksi jarak dengan tarif terhadap investasi teknologi memiliki hasil yang sama dengan yang ditemukan oleh Iacovone (2012). Penelitiannya menemukan bahwa jarak berkorelasi negatif dan signifikan terhadap investasi teknologi, sedangkan pada penelitian ini hasilnya negatif tetapi tidak signifikan. Hal ini di duga terjadi karena perbedaan tahun sampel yang digunakan pada penelitian Iacovone (2012) yaitu tahun 1993-2002 sedangkan penelitian ini menggunakan data tahun 2003-2014 di mana pada tahun tersebut pembuat kebijakan di Meksiko mulai fokus pada liberalisasi tarif untuk meningkatkan ekonomi pada tahun 1990an. Dengan demikian di duga rata-rata gap teknologi masih besar untuk perusahaan di Meksiko dibandingkan Indonesia yang telah melewati krisis global tahun 1998 sehingga perusahaan yang bertahan sampai tahun tersebut sudah lebih efisien, sedangkan untuk korelasi antara interaksi jarak dan tarif terhadap investasi teknologi memiliki hasil yang sama dengan penelitian Iacovone (2012).

\section{SIMPULAN DAN SARAN}

Dampak penurunan tarif terhadap investasi teknologi masih bisa diperdebatkan. Penurunan tarif akan mendorong investasi teknologi perusahaan dengan gap teknologi yang kecil namun akan menurunkan perusahaan investasi teknologi dengan kesenjangan teknologi yang besar (Aghion et al., 2004, 2005). Di sisi lain, pengurangan tarif akan meningkatkan investasi teknologi kedua perusahaan dengan kesenjangan teknologi kecil dan besar (Iacovone, 2012). Berdasarkan hasil analisis yang dilakukan pada penelitian ini dapat disimpulkan bahwa liberalisasi tarif meningkatkan investasi teknologi rata-rata seluruh perusahaan. Semakin besar penurunan tarif maka semakin besar investasi yang dilakukan perusahaan (cateris paribus) baik untuk perusahaan dengan gap teknologi yang besar maupun kecil. Selain itu, kesenjangan teknologi antara perusahaan domestik dan asing mendorong perusahaan domestik untuk meningkatkan upaya untuk menjadi lebih efisien dengan investasi teknologi. Hasil penelitian ini sejalan dengan studi Iacovone (2012) dan Liebman dan Reynolds (2015) yang menunjukkan bahwa tarif output berdampak negatif terhadap investasi teknologi.

Selain itu, diketahui bahwa terdapat kesenjangan yang cukup besar antara perusahaan dengan gap teknologi yang kecil dan yang besar pada perusahaan manufaktur di Indonesia. Semakin kecil gap teknologi manufaktur di Indonesia semakin besar investasi teknologi yang dilakukan. Meskipun demikian, data menunjukkan rata-rata perusahaan manufaktur Indonesia berada pada posisi backward firm di mana investasi teknologi dilakukan untuk bertahan. Hal ini diduga akibat teknologi yang digunakan bukanlah teknologi terbaru.

Dikarenakan keterbatasan data dan waktu, penelitian ini tidak membedakan dampak tarif input dan tarif output terhadap investasi teknologi. Berdasarkan penelitian Kandilov dan Leblebiciog `lu (2012) dan Liebman dan Reynolds, (2015) dampak kedua tarif tersebut berbeda. Untuk itu, diharapkan penelitian selanjutnya dapat menganalisis dampak tarif input dan tarif output secara terpisah.

Selain itu, penelitian ini tidak menghitung seberapa besar gap teknologi perusahaan di dalam negeri dan perusahaan 
asing hanya arahnya. Keterbatasan tersebut menjadi kelemahan lain penelitian ini. Dugaan adanya kesalahan perhitungan jarak juga menjadi kelemahan penelitian ini. Diharapkan penelitian selanjutnya dapat melakukan perhitungan gap teknologi dengan metode yang lain.

\section{DAFTAR PUSTAKA}

Aghion, P. 2002. Schumpeterian Growth Theory and the Dynamics of Income Inequality. Econometrica 70(3): 855-882.

Aghion, P., R. Blundell., R. Griffith., P. Howitt, dan S. Prantl. 2004. Entry and productivity growth: evidence from micro-level panel data. Journal of the European Economic Association 2(2/3): 265-276.

Aghion, P., S. Redding., R. Burgess., dan F. Zilibotti. 2005. Entry Liberalization and Inequality in Industrial Performance. Journal of the European Economic Association 3(2/3): 291-302.

Amiti, B. M., dan J. Konings. 2007. Trade Intermediate and Productivity: Liberalization, Inputs, from Indonesia Evidence. The American Economic Review 97(5): 1611-1638.

Athukorala, P. C., dan A. Kohpaiboon. 2010. Globalization of $\mathrm{R}$ dan $\mathrm{D}$ by US-based multinational enterprises. Research Policy 39(10): 1335-1347.

Bustos, P. 2011. Trade Liberalization, Exports, and Technology Upgrading: Evidence on the Impact of MERCOSUR on Argentinian Firms. The American Economic Review 101(February): 304-340.

Ederington, J., dan P. Mccalman. 2011. Infant industry protection and industrial dynamics. Journal of International Economics 84(1): 37-47.

Fernandes, A. M. 2007. Trade policy, trade volumes and plant-level productivity in Colombian manufacturing industries. Journal of International Economics 71: 5271.

Goh, A. T. 2000. Opportunity cost, trade policies and the efficiency of firms. Journal of Development Economics 62(2):
363-383.

Hendricks, L. 2000. Equipment investment and growth in developing countries. Journal of Development Economics 61: 335364.

Iacovone, L. 2012. The better you are the stronger it makes you: Evidence on the asymmetric impact of liberalization. Journal of Development Economics 99(2): 474-485.

Kandilov, I. T., dan A. Leblebiciog `u. 2012. Trade Liberalization and Investment: Firm-level Evidence from Mexico. The World Bank Economic Review 26(2): 320349.

Kandilov, I. T., dan A. Leblebicioğlu. 2011. The impact of exchange rate volatility on plant-level investment: Evidence from Colombia. Journal of Development Economics Journal 94(2): 220-230.

Liebman, B. H., dan K.M. Reynolds. 2015. Trade Liberalisation and Capital Spending by US Manufacturers. The World Economy 38(11):1763-1780.

Miyagiwa, K., dan Y. Ohno. 1995. Closing the Technology Gap Under Protection. American Economic Association 85(4): 755770 .

Nickel, S. J. 1996. Competition and Corporate Performance. Journal of Political Economy 104(4): 724-746.

Okamoto, Y., dan F. Sjöholm. 2001. Technology development in Indonesia. The European Institute of Japan Studies Working Paper No. 124: Mei 2001.

Orlikowski, W. J. 1992. The Duality of Technology: Rethinking the Concept of Technology in Organizations. Institute for Operations Research and the Management Sciences 3(3): 398-427.

Parameswaran, M. 2010. International trade and $\mathrm{R}$ dan $\mathrm{D}$ investment: evidence from manufacturing firms in India. International Journal Technology and Globalisation 5: 43-60.

Pavcnik, N. 2002. Trade Liberalization, Exit, and Productivity Improvements: Evidence from Chilean Plants. Review of Economic Studies 69(1): 245-276. 
Ridhwan, M. M., G. Wicaksono., L. Nurliana., P. Bary., F.T. Suryani., dan R. Satyanugroho. 2015. Industri Nasional Di Era Masyarakat Ekonomi Asean Dan Perdagangan Bebas. Bank Indonesia Working Paper (WP/3/2015) : September 2015.

Rodrik, D. 1988. Closing The Technology Cap: Does Trade Liberalization Really Help?. NBER Working Paper No. 2654: July 1988.

Schor, A. 2004. Heterogeneous productivity response to tariff reduction. Evidence from Brazilian manufacturing firms. Journal of Development Economics 75(2 SPEC. ISS.): 373-396.
Thoenig, M., dan T. Verdier. 2003. A Theory of Defensive Skill-Biased Innovation and Globalization. The American Economic Review 93(3): 709-728.

Topalova, P., dan A. Khandelwal. 2011. Trade Liberalization and Firm Productivity: The Case of India. The Review of Economics and Statistics 93(3): 995-1009.

Tybout, J. R., dan M.D. Westbrook. 1994. Trade liberalization and the dimensions of efficiency change in Mexican manufacturing industries. Journal of International Economics 39(0): 53-78.

Vives, X. 2008. Innovation and Competitive Pressure. The Journal of Industrial Economics 56(3): 419-469. 